\title{
Vegetasi Habitat Komodo dalam Bentang Alam Riung dan Pulau Ontoloe di Nusa Tenggara Timur
}

\section{Willem Amu Blegur', Tjut Sugandawaty Djohan² dan Su Ritohardoyo ${ }^{3}$}

Mahasiswa Sekolah Pascasarjana Ilmu Lingkungan Universitas Gadjah Mada, Yogyakarta, Indonesia ${ }^{1}$, Fakultas Biologi Universitas Gadjah Mada, Yogyakarta Indonesia ${ }^{2}$, Fakultas Geografi Universitas Gadjah Mada, Yogyakarta, Indonesia ${ }^{3}$

Email koresponden:willem_blegur@yahoo.com

Diterima: 12 Desember 2016/Disetujui: 22 Februari 2017 / Publikasi online: 31 Maret 2017

(c) 2017 Fakultas Geografi UGM dan Ikatan Geograf Indonesia (IGI)

\begin{abstract}
Abstrak Penelitian ini mengkaji vegetasi habitat komodo dalam bentang alam Riung dan Ontoloe. Ekosistem karst mendominasi di Riung dan Ontoloe. Lokasi kajian merupakan taman nasional yaitu CA Wolo Tado, CA Riung dan TWAL 17 Pulau. Taman nasional ditetapkan pada tahun 1992 dan 1996. Pembakaran sabana di hutan sabana atau savanna woodland dengan skala kecil menjaga ketersediaan sabana di Pulau Besar, Flores. Sabana tersebut merupakan sumber makanan bagi pakan komodo yaitu rusa (Cervus timorensis). Sebaliknya, di Pulau Kecil atau Ontoloe tidak ada pembakaran sabana berskala kecil. Secara khusus, penelitian ini, mempelajari: a) tipe ekosistem penyusun bentang alam Pulau Besar dan Pulau Kecil; b) cacah jenis, densitas dan growth form vegetasi habitat; c) kualitas fisiko kimia tanah yaitu temperatur, tekstur, $\mathrm{pH}, \mathrm{NO} 3, \mathrm{NH} 4, \mathrm{PO} 4, \mathrm{~K}$ tersedia; udara yaitu temperatur dan salinitas air ekosistem hutan bakau. Data dikoleksi dengan kuadrat plot dengan bantuan transek. Ukuran plot pada ekosistem hutan bakau, hutan ekoton dan hutan legong $20 \mathrm{mx} 20 \mathrm{~m}$ dengan ulangan $4 \mathrm{x}$. Sedangkan padang rumput yang jarang pohon, ukuran plot 100mx100m dengan ulangan 4x. Data dicuplik berupa: cacah jenis, densitas dan growth form penyusun vegetasi. Data fisikokimia tanah, udara dan air dicuplik di bawah kanopi dan gap kanopi. Hasil yang diperoleh tipe ekosistem habitat di Pulau Besar lebih banyak daripada di Pulau Kecil yaitu ekosistem hutan bakau, hutan ekoton, hutan sabana, dan hutan legong. Cacah jenis, densitas dan growth form di Pulau Besar juga lebih tinggi daripada di Pulau Kecil. Hal ini merespon tekstur tanah, kadar NO3, kadar NH4 dan temperatur. Pada Pulau Kecil, ditemukan ancaman dengan densitas yang cukup tinggi per 4 ha yaitu sapling L. glauca 179 individu, A. lebbeck 353 individu dan semak L. camara 169 individu. Hal ini membuktikan bahwa pembakaran hutan sabana dengan skala kecil menjaga ketersediaan sabana di Pulau Besar, sehingga komodo akan terlindungi.
\end{abstract}

Kata kunci: komodo, hutan bakau, hutan legong, hutan sabana.

\begin{abstract}
This study examines the vegetation of Komodo habitat in the Riung and Ontoloe landscapes. The karst ecosystem dominates in Riung and Ontoloe. The study location is a national park of CA Wolo Tado, CA Riung and TWAL 17 Islands. National parks were set in 1992 and 1996. The savanna fires in savanna woods or small-scale savanna woodland keep the availability of savannas on the Great Island of Flores. Sabana is a source of food for feeding dragons deer (Cervus timorensis). On the other hand, on Small Island or Ontoloe there is no small scale savanna burning. Specifically, this study, studied: a) the type of ecosystem composing the landscape of Big Island and Small Islands; B) count type, density and growth form of habitat vegetation; C) quality of soil chemical physics ie temperature, texture, $\mathrm{pH}, \mathrm{NO}$, NH4, PO4, K available; Air that is temperature and salinity water ecosystem of mangrove forest. Data collected with square plot with transect help. The plot size of the mangrove ecosystem, the ecoton forest and the $20 \mathrm{mx} 20 \mathrm{~m}$ legong forest with $4 x$ replications. While a rare meadow of trees, plot size $100 \mathrm{~m} \times 100 \mathrm{~m}$ with $4 \times$ repeat. The data is cultivated in the form of: count type, density and growth form of vegetation. Physicochemical data of soil, air and water are collected under canopy and canopy gap. The results obtained by habitat ecosystem type in Pulau Besar are more than in Small Island, ie mangrove forest ecosystem, ecoton forest, savannah forest, and forest legong. Character type, density and growth form on the Big Island is also higher than in Small Island. It responds to soil texture, NO3 levels, NH4 levels and temperature. On Small Island, there were threats with high density per 4 ha ie Sapling L. glauca 179 individuals, A. lebbeck 353 individuals and L. camara bushes 169 individuals. This proves that small-scale savage forest savings keep the availability of savannas on the Big Island, so that the Komodo dragon will be protected.
\end{abstract}

Keywords: Dragons, mangrove forests, forest legong, forest savannas

\section{PENDAHULUAN}

Kehadiran ekosistem penyusun bentang alam Pulau Besar dan Pulau Kecil mendukung keberlanjutan populasi komodo (Varanus komodoensis). Pada tahun 1992 dan 1996, sebagian Pulau Besar dan Pulau Kecil ditetapkan sebagai taman nasional, meliputi Cagar Alam (CA) Wolo Tado, CA Riung dan Taman Wisata
Alam Laut (TWAL) 17 Pulau. Pulau Besar atau Flores dan Pulau Kecil atau Ontoloe merupakan pulau di bagian Utara daerah Riung, Nusa Tenggara Timur (NTT). Bentang alam karst mendominasi Pulau Besar dan Pulau Kecil. Tipe ekosistem yang ditemukan merespon bentang alam karst yaitu daerah dengan ketersediaan air tanah yang sedikit (IUCN 2008) dan 
lapisan tanah yang tipis (Achmad 2011).

Tipe ekosistem yang terdistribusi dari lowland ke upland yaitu ekosistem hutan bakau, ekosistem hutan ekoton dan ekosistem hutan bukit yang terdiri dari ekosistem hutan sabana atau savanna woodland dan ekosistem hutan legong. Kehadiran ekosistem hutan bakau diatur oleh salinitas, substrat lumpur dan tinggi muka air (Walter 1971). Tipe ekosistem hutan bakau fringe terletak di sepanjang pantai, sering dihantam gelombang dan siklus hara yang terbatas, maka memerlukan adaptasi yang baik. Bentuk adaptasi dapat morfologi dan fisiologi seperti membentuk sistem akar napas yaitu Sonneratia alba; membentuk akar tunjang seperti R. mucronata, R. stylosa; membentuk akar lutut seperti Bruguiera cylindrica, B. gymnorrhiza dan akar papan seperti Ceriops tagal. (Kitamura et al. 1997; Mitsch dan Gosselink 2000). Auffenberg (1981) menemukan jenis penyusun ekosistem hutan bakau di Pulau Besar yaitu A. alba, R. mucronata, L. racemosa, L. littorea, E. agalloca, Sonneratia sp dan Bruguiera sp. Hidayatullah (2013) mempelajari pemanfaatan hutan bakau oleh masyarakat NTT seperti kulit batang dan batang R. mucronata sebagai obat demam dan bahan pagar; kulit akar B. gymnorrhiza sebagai obat gigitan buaya dan kulit batang C. tagal sebagai obat mual.

Ekosistem hutan ekoton merupakan ekosistem antara ekosistem hutan bakau dan ekosistem hutan sabana. Tipe ekosistem hutan ekoton di Pulau Besar, khususnya di Wolo Tado telah diubah menjadi jalan raya. Sedangkan di Riung, tidak ditemukan ekosistem hutan ekoton sebab langsung berbatasan dengan tebing atau cliff. Ekosistem hutan ekoton di Pulau Kecil telah dikoloni oleh semak Lantana camara. Seperti dijelaskan sebelumnya, bentang alam karst mendominasi Pulau Besar dan Pulau Kecil maka kehadiran komunitas vegetasi di ekosistem karst sebagai respon terhadap karst. Achmad (2011) menyatakan komunitas tumbuhan karst memiliki kemampuan adaptasi tinggi terhadap kekurang air, lapisan air tanah yang tipis dan kemiringan topografi. Usikan yang terjadi di karst cenderung berubah ke arah negatif sehingga penebangan, pengubahan bentuklahan dan revegetasi harus bijak (Fuping et al 2007; Yuan et al 2011; Zhu et al 2011; Liu et al 2012; Xiangkung et al 2013; Lu et al 2014).

Walter (1971) menyatakan ekosistem hutan sabana merupakan tipe ekosistem yang ditemukan di zona tropical summer-rain. Ekosistem ini merupakan padang rumput yang diselingi oleh pohon berkayu seperti Borassus flabeliber. Kehadiran ekosistem ini didukung oleh iklim yaitu temperatur dan curah hujan yang sedikit. Iklim mempengaruhi kondisi tanah, terutama di bentang alam karst. Vegetasi yang ada beradaptasi dengan mengeringkan ujung daun dan menggugurkan daun, tapi tidak sampai ke bagian pangkal daun. Selain itu, vegetasi memiliki sistem perakaran yang panjang untuk memperoleh air tanah. Semak dan rumput merupakan growth form yang cocok untuk hidup di kondisi tersebut, sebab mengembangkan r-seleksi dan K-seleksi (Barbour et al. 1987). Kehadiran rumput dan semak muda penting bagi pakan komodo yaitu rusa, kerbau, kambing. Rumput H. contortus ditemukan dalam diet rusa (de Garine-Wichatitsky et al. 2005; Ginantra et al. 2014). Untuk menjaga ketersediaan hutan sabana, pembakaran skala kecil dan kontinu perlu dilakukan sehingga tidak ada invasi semak (Barbour et al. 1987; Walker dan Smith 1997).

Ekosistem hutan legong merupakan komunitas tumbuhan yang hidup di antara cekungan dua bukit. Komunitas tumbuhan dalam ekosistem hutan legong merupakan komunitas semi-evergreen dan desiduous. Walter (1971) menyatakan hutan semi-evergreen dan hutan desiduous selalu menggugurkan daun minimal sekali dalam setahun. Fenomena ini dipengaruhi terutama oleh peningkatan temperatur dan diikuti oleh ketersediaan air. Vegetasi yang menggugurkan daun, menjaga kehidupan. Daun dan bunga bertumbuh lagi sebelum tiba musim hujan. Kurang tersedianya air diadaptasi dengan daun yang berstruktur xeromorfik dan menggugurkan daun seperti pada Eucalyptus, Acacia, Ilex, Hedera. Bentuk adaptasi lain dengan membentuk duri seperti Acacia dan semak, kemampuan menyimpan air yang banyak dan memperlambat jatuhnya buah seperti Adansonia digitata. Rumput mematikan ujung daun, tapi tidak pada bagian pangkal. Ekosistem hutan legong ditemukan di upland Pulau Besar. Di Pulau Kecil, ekosistem hutan legong sangat sempit.

Distribusi alami komodo (V. komodoensis) di bentang alam barat dan utara Nusa Tenggara Timur (Ouwens 1912), mulai dari 0-700 m dpl (Ciofi dan de Boer 2004). Saat ini komodo bertstatus terancam (IUCN 2004) dan dicatat dalam redlist appendix 1 (UNEP-CITES 2013). Perlindungan binatang liar harus dilakukan dengan perlindungan habitat (Primack et al. 1998) seperti komodo. Komodo ditemukan di Pulau Besar yaitu Pulau Flores dan beberapa pulau kecil yaitu Pulau Komodo, Pulau Rinca, Pulau Gili Motang dan Pulau Gili Dasami (Auffenberg 1981). Komodo juga ditemukan di Pulau Ontoloe (KSP 2014: pers comm). Ciofi dan de Boer (2004) menemukan komodo yang ada di daerah ini dengan tipe vegetasi yaitu hutan monson deciduous kering, sabana dan padang rumput. Iklim kering dan angin monson memunculkan vegetasi yang berbeda di bentang alam seperti hutan monson, sabana, stepa, sedikit mangrove di pesisir pantai. Bentang alam karst tidak memiliki air yang cukup bagi organisme. Vegetasi karst-monsoon mampu beradaptasi pada kelangkaan air. Rumput mengoptimalkan ketersediaan air dan terjaga oleh api yaitu pada kebakaran sistem ekologis hutan sabana. Pada ekosistem tersebut, komodo berhabitat dan berinteraksi seperti bersarang (Jessop et al 2004), mencari mangsa (Ciofi dan de Boer 2004) dan termoregulasi (Harlow et al 2010) .

Pembakaran saana di hutan sabana di Pulau Besar dalam skala kecil akan menjaga keberlanjutan sabana 
sebagai suplai makanan untuk C. timorensis, B. taurus dan C. aegagrus. Setelah pengubahan status tahun 1992 dan 1996, sebagian ekosistem dan lahan warga diubah status menjadi CA Wolo Tado, CA Riung dan TWAL 17 Pulau. Pemerintah melarang pembakaran sabana. Hal tersebut mengganggu ketersediaan sabana di hutan sabana di Pulau Besar sehingga menimbulkan kompetisi antara C. timorensis, B. taurus dan C. aegagrus. Sebaliknya, sabana di Pulau Kecil tidak mengalami pembakaran dalam skala kecil oleh masyarakat. Ancaman di Pulau Kecil yaitu invasi semak.

Secara spesifik penelitian mempelajari: 1). Tipe ekosistem penyusun bentanglahan di Pulau Besar dan Pulau Kecil. 2). Cacah jenis, densitas dan growth form penyusun vegetasi habitat komodo; 3). Kondisi hutan legong pada saat musim hujan; 4). Kondisi kualitas fisiko kimia tanah yang meliputi tekstur (clay, silt, sand), temperatur, $\mathrm{pH}$ dan unsur hara yaitu NO3, NH4, PO4, K tersedia; temperatur udara; dan salinitas air hutan bakau.

\section{METODE PENELITIAN}

Pengambilan data dilakukan untuk mengambil data vegetasi habitat komodo dan parameter fisiko kimia. Pengambilan data vegetasi habitat dilakukan di Pulau Besar dan Pulau Kecil menggunakan metode kuadrat plot yang dengan bantuan transek dari bukit ke lowland (Gambar 1, 2). Ukuran plot untuk mencuplik data di ekosistem hutan bakau yaitu 20m x 20m dengan ulangan 4x. Zona di Pulau Besar yaitu Wolo Tado dan Riung hanya zona middle. Zona di Pulau Ontoloe ada dua zona yaitu zona middle dan zona upper. Pencuplikan data untuk ekosistem hutan ekoton, ekosistem hutan sabana dan ekosistem hutan legong disesuaikan dengan kemampuan akses dan luas di daerah kajian (Tabel 1). Data hutan sabana dicuplik dengan kuadrat plot berukuran $100 \mathrm{~m}$ x 100m karena jarak antara individu growth form pohon yang berjauhan. Luas area dikonversi ke satuan hektar. Tiap plot dipilah menjadi empat kuadran. Pengambilan data per cacah spesies dan individu spesies penyusun growth form pohon, sapling dan seedling.

Parameter growth form pohon, sapling, semak dan vegetasi lantai yang diukur meliputi : cacah jenis, jumlah jenis cacah individu, densitas setiap jenis, tinggi total (ttotal), tinggi cabang pertama (tcp), keliling batang, panjang dan lebar kanopi dan keliling rumpun. (Djohan 2014). Parameter fisiko kimia tanah dan udara akan diambil di bawah vegetasi dan di gap vegetasi. Data fisik tanah berupa tekstur dan kimia tanah berupa keasaman $(\mathrm{pH})$ dan unsur hara yaitu NO3, $\mathrm{NH} 4, \mathrm{PO} 4$ dan $\mathrm{K}$ tersedia. Unsur hara diukur diukur di laboratorium tanah Fakultas Pertanian UGM. Tanah diambil 500 gram tiap kuadran untuk 4 kuadrat plot per lokasi.

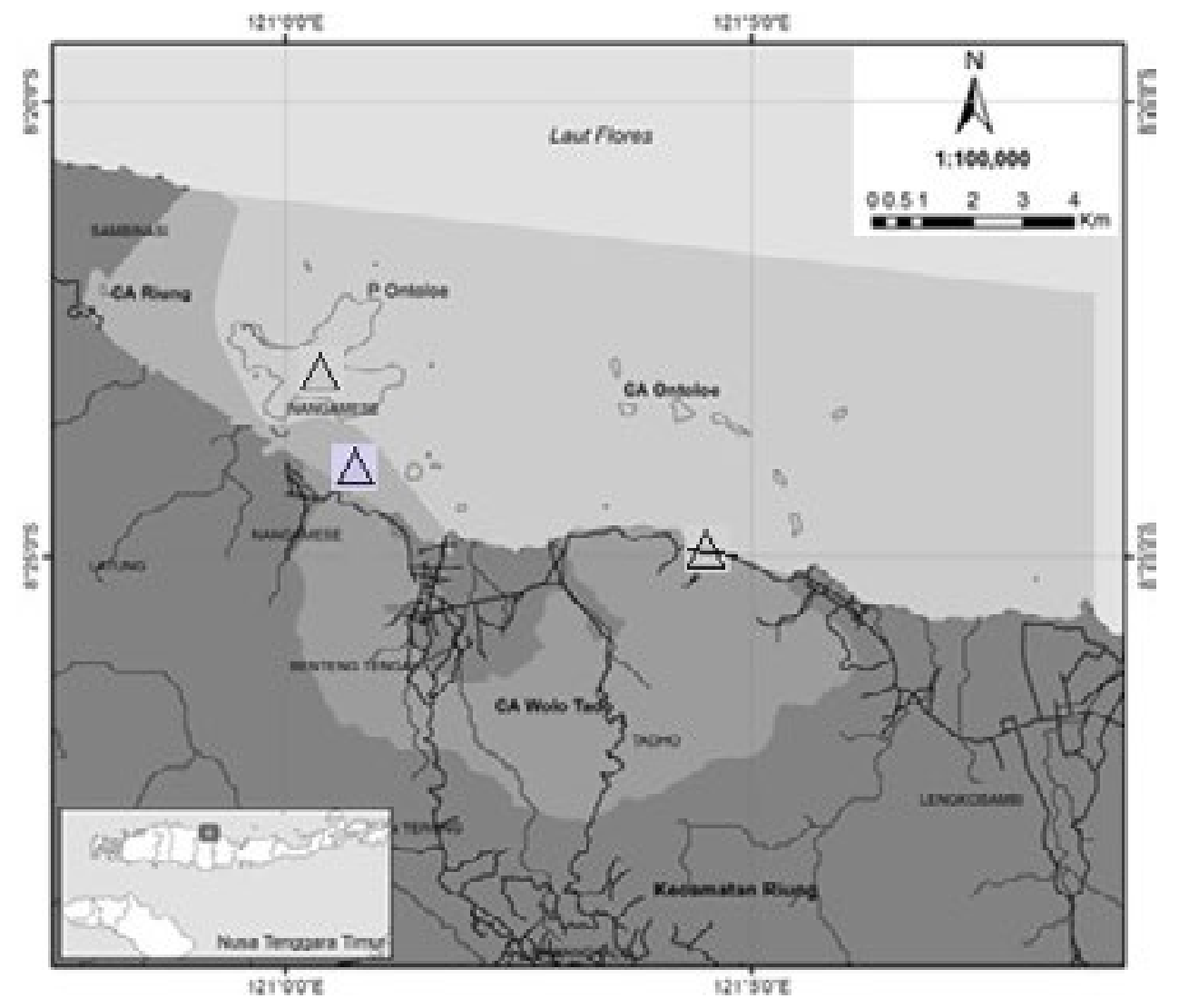

Gambar 1. Peta Lokasi Penelitian: : Jalan, : Sungai, : CA Wolo Tado, : CA Riung : TWAL 17 Pulau atau Ontoloe, : Lokasi pengambilan data vegetasi. 


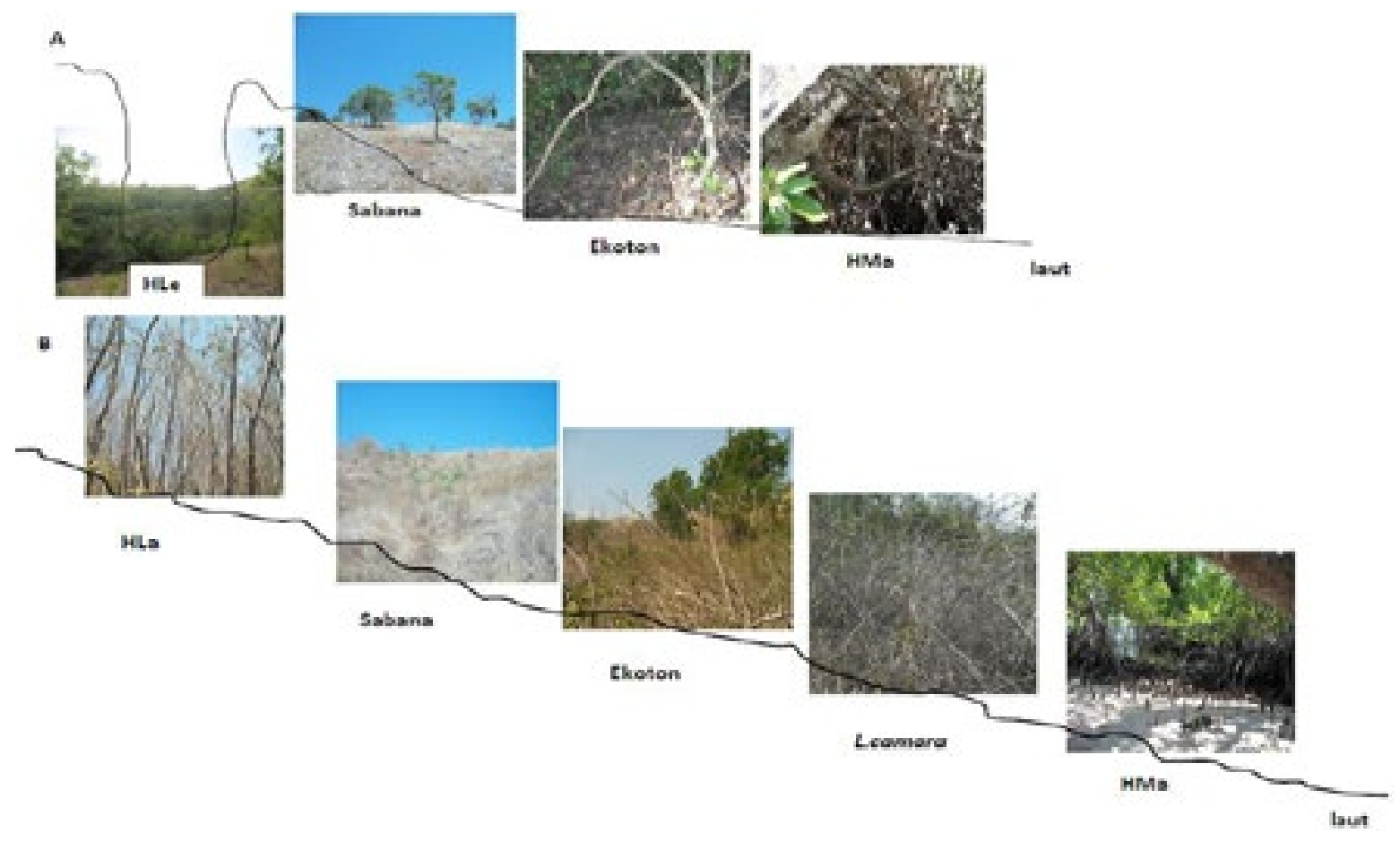

Gambar 2. Tipe ekosistem: A). Tipe lokasi pulau besar (HLe=hutan legong, HMa=hutan mangrove); B). Tipe lokasi pulau kecil ( $\mathrm{HLa}=$ hutan lamtoro)

Tiap kuadrat plot akan dicampur dan diambil 500 gram per lokasi. Temperatur diukur dengan termometer alkohol yang dimasukkan ke dalam tanah $10 \mathrm{~cm} . \mathrm{pH}$ tanah menggunakan $\mathrm{pH}$ homekittester yang dimasukkan ke dalam tanah $10 \mathrm{~cm}$. Pengukuran fisik udara meliputi : temperatur diambil di bawah vegetasi dan gap vegetasi. Salinitas diukur dari sampel komposit sampel air ekosistem hutan bakau yang diukur di laboratorium.

Perhitungan dan Analisis Data - Perhitungan dan analisis data habitat komodo dengan melakukan perhitungan nilai penting menggunakan persamaan yang ditulis Brewer dan Zar (1984) :

Densitas species $\mathrm{A}=$ cacah individu sp. A luas area

Densitas Relatif species A= cacah jumlah spesies A x $\quad 100 \%$ densitas seluruh spesies

Frekuensi species $\mathrm{A}=$ jumlah plot ditemukan spesies $\mathrm{A}$ jumlah seluruh plot

Frekuensi Relatif species A= frekuensi spesies A x100\%

LBA species $\mathrm{A} \quad=\pi(\mathrm{r} \text { batang species } \mathrm{A})^{2}$ frekuensi seluruh spesies

LBA Relatif species A = LBA species A per LBA seluruh species $\mathrm{x} 100 \%$

Luas kanopi spesies $\mathrm{A}=\pi(\mathrm{p} \times \mathrm{l})$ kanopi

Luas relatif kanopi spesies $A=$ luas kanopi spesies A x100\% luas kanopi seluruh spesies

NP (Nilai Penting) species A $=$ DR (densitas relatif) species $A+F R$ (frekuensi relatif) species A + luas kanopi relatif species A + luas basal area relatif spesies A
Indeks similaritas dan ordinasi - Perhitungan indeks similaritas (index of similarity $=$ IS) di antara kedua stand yang dibandingkan menggunakan indeks similaritas Sorensen (Muller-Dumbois dan Ellenberg 1974) dengan menggunakan rumus: ISsoreness $=.(\mathrm{A}=$ jumlah semua nilai kuantitatif pada stand $A ; B=$ jumlah semua nilai kuantitatif pada stand $B ; \mathrm{W}=$ jumlah nilai kuantitatif terkecil dari dua nilai spesies yang umum terdapat pada kedua stand yang dibandingkan). Data yang ditabulasi akan dilanjutkan dengan membuat gambar ordinasi menurut tipe ekosistem Pulau Besar dan Pulau Ontoloe. Analisis dilakukan untuk mempelajari faktor fisiko-kimia dan manusia yang mempengaruhi kemiripan kondisi vegetasi penyusun habitat komodo.

\section{HASIL DAN PEMBAHASAN}

Tipe ekosistem di Pulau Besar dan Pulau Kecil meliputi ekosistem hutan bakau, ekosistem hutan ekoton, ekosistem hutan sabana atau savanna woodland dan ekosistem hutan legong (Gambar 3). Pulau Besar atau Flores memiliki keempat tipe ekosistem. Sebaliknya, Pulau Kecil atau Ontoloe hanya memiliki tiga tipe ekosistem. Ukuran ekosistem hutan legong sempit sehingga tidak dilakukan pengukuran. MacArthur dan Wilson (1963) menyatakan bahwa Pulau Besar menyediakan habitat lebih banyak daripada di Pulau Kecil.

Ekosistem hutan bakau - Ekosistem hutan bakau di Pulau Kecil memiliki 2 zona yaitu zona middle dan upper. Zona upper di Wolo Tado tidak ada sebab sudah 
Willem Amu Blegur dkk/Majalah Geografi Indonesia, Vol. 31 No.1, Maret 2017 : 95 - 111

Tabel 1. Lokasi pengambilan data vegetasi habitat komodo di Pulau Besar dan Pulau Kecil

\begin{tabular}{|c|c|c|c|c|}
\hline Tipe Ekosistem & Lokasi & Plot ke-n & Luas (ha) & Koordinat GPS \\
\hline \multirow[t]{16}{*}{ Hutan bakau } & $\begin{array}{l}\text { Wolo Tado zona } \\
\text { middle }\end{array}$ & 1 & 0,16 & S: 08024'57.60”/ S: 121004'42.95” \\
\hline & & 2 & & S: 08024'57.02”/ S: 121004'42.16" \\
\hline & & 3 & & S: 08024'58.83"/ S: 121004'49.92" \\
\hline & & 4 & & S: 08024'59.64"/ S: 121004'47.16" \\
\hline & $\begin{array}{l}\text { Riung zona } \\
\text { middle }\end{array}$ & 1 & 0,16 & S: 08024’30.28”/ S: 121001'08.20" \\
\hline & & 2 & & S: 08024'24.79"/ S: 121001'07.59" \\
\hline & & 3 & & S: 08024'11.33”/ S: 121000'55.62” \\
\hline & & 4 & & S: 08024’08.73”/ S: 121000'46.61" \\
\hline & $\begin{array}{l}\text { Ontoloe zona } \\
\text { middle }\end{array}$ & 1 & 0,16 & S: 08022’39.81”/ S: 121000'44.19” \\
\hline & & 2 & & S: 08022'40.29”/ S: 121000'41.28” \\
\hline & & 3 & & S: 08022'42.56”/ S: 121000'36.97” \\
\hline & & 4 & & S: 08022’45.19”/ S: 121000'29.42” \\
\hline & $\begin{array}{l}\text { Ontoloe zona } \\
\text { upper }\end{array}$ & 1 & 0,16 & S: 08022’32.32”/ S: 121000’37.16” \\
\hline & & 2 & & S: 08022’34.53”/ S: 121000’39.83” \\
\hline & & 3 & & S: 08022'36.04”/ S: 121000'40.43” \\
\hline & & 4 & & S: 08022’36.15”/ S: 121000’39.00” \\
\hline \multirow[t]{7}{*}{ Hutan ekoton } & Wolo Tado & 1 & 0,16 & S: $08025^{\prime} 02.45^{\prime \prime} /$ S: $121004^{\prime} 34.16^{\prime \prime}$ \\
\hline & & 2 & & S: $08025^{\prime} 02.85^{\prime \prime} / \mathrm{S}: 121004^{\prime} 32.60^{\prime \prime}$ \\
\hline & & 3 & & S: $08025^{\prime} 02.65^{\prime \prime} /$ S: $121004^{\prime} 30.98^{\prime \prime}$ \\
\hline & & 4 & & S: 08025’02.43”/ S: 121004'26.97” \\
\hline & Ontoloe & 1 & 0,06 & S: 08022'32.19”/ S: 121000'42.24” \\
\hline & & 2 & & S: 08022’31.35”/ S: 121000’37.60” \\
\hline & & 3 & & S: 08022’31.49”/ S: 121000’37.60” \\
\hline \multirow[t]{12}{*}{ Hutan sabana } & Wolo Tado & 1 & 1,00 & S: 08022'06.36”/ S: 121004'33.42” \\
\hline & & 2 & & S: $08025^{\prime} 08.76^{\prime \prime} /$ S: $121004^{\prime} 33.37^{\prime \prime}$ \\
\hline & & 3 & & S: $08025^{\prime} 10.97^{\prime \prime} / \mathrm{S}: 121004^{\prime} 35.15^{\prime \prime}$ \\
\hline & & 4 & & S: $08025^{\prime} 11.09^{\prime \prime} /$ S: $121004^{\prime} 32.13^{\prime \prime}$ \\
\hline & Riung & 1 & 4,00 & S: 08024'10.22”/ S: 121000'30.71" \\
\hline & & 2 & & S: 08023'54.81”/ S: 121000'48.78” \\
\hline & & 3 & & S: 08023’58.40”/ S: 121000’48.20” \\
\hline & & 4 & & S: 08024'05.56”/ S: 121000'21.92” \\
\hline & Ontoloe & 1 & 3,60 & S: 08022’31.75”/ S: 121000’22.11” \\
\hline & & 2 & & S: 08022’34.65”/ S: 121000’26.78” \\
\hline & & 3 & & S: 08022'41.96”/ S: 121000'23.35” \\
\hline & & 4 & & S: 08022'48.04”/ S: 121000'18.95” \\
\hline \multirow[t]{8}{*}{ Hutan legong } & Wolo Tado & 1 & 0,15 & S: $08025^{\prime} 09.56^{\prime \prime} /$ S: $121004^{\prime} 40.98^{\prime \prime}$ \\
\hline & & 2 & & S: $08025^{\prime} 13.17^{\prime \prime} /$ S: $121004^{\prime} 35.34^{\prime \prime}$ \\
\hline & & 3 & & S: $08025^{\prime} 10.13^{\prime \prime} /$ S: $121004^{\prime} 40.89^{\prime \prime}$ \\
\hline & & 4 & & S: 08025'10.39”/ S: 121004'39.74" \\
\hline & Riung & 1 & 0,16 & S: $08024^{\prime} 08.90^{\prime \prime} /$ S: $121000^{\prime} 36.67^{\prime \prime}$ \\
\hline & & 2 & & S: 08024'27.57”/ S: 121000'28.48” \\
\hline & & 3 & & S: 08024'32.81”/ S: 121000'24.69” \\
\hline & & 4 & & S: 08024'34.06”/ S: 121000'28.34" \\
\hline
\end{tabular}


diubah menjadi jalan raya. Zona upper di Riung tidak ada sebab langsung berbatasan dengan tebing. Zona lower tidak ditemukan di Pulau Besar dan Pulau Kecil sebab merupakan daerah laut.

Di bagian belakang ekosistem hutan bakau, ditemukan dataran garam atau saltpan yaitu cekungan dangkal yang diisi oleh air laut saat air pasang. Ketika surut, air laut tergenang dan oleh panas matahari menguapkan air sehingga tersisa garam yang membentuk saltpan (Walter 1971).

Jenis Rhizophora mucronata mendominasi zona middle di Pulau Besar dan Pulau Kecil. Kami menemukan bahwa dalam 0,16 ha terdapat 77 pohon di CA Wolo Tado, 62 pohon di CA Riung dan 89 pohon di TWAL 17 Pulau. Sedangkan sapling R. mucronata ditemukan di CA Wolo Tado 17 individu, CA Riung
103 individu dan TWAL 111 individu. Selain itu ditemukan 129 sapling Brugueira stylosa. Kedua jenis ini beradaptasi dengan tekstur tanah berpasir $(59,81 \%$ dan 97,33\%) dan salinitas air (110 0/00 dan 100 0/00) sehingga tumbuh dengan baik (Gambar 7 dan 9).

Jenis R. mucronata memiliki perakaran tunggang yang baik dan B. stylosa dengan akar banir tumbuh ke dalam tanah dan memperkokoh tumbuhan bakau tersebut. Salinitas yang tinggi diadaptasi dengan daun yang memiliki kelenjar garam (Kitamura et al 1997). R. mucronata di Pulau Ontoloe memanfaatkan kadar NH4 tinggi (121,31 ppm) untuk tumbuh dengan baik yang berasal dari kotoran Cynoptera sp.

Ceriops tagal mendominasi zona upper di Pulau Ontoloe. Kami menemukan $80 \%$ sapling dari 1074 individu per 0,16 ha berada di gap vegetasi (Gambar 4).

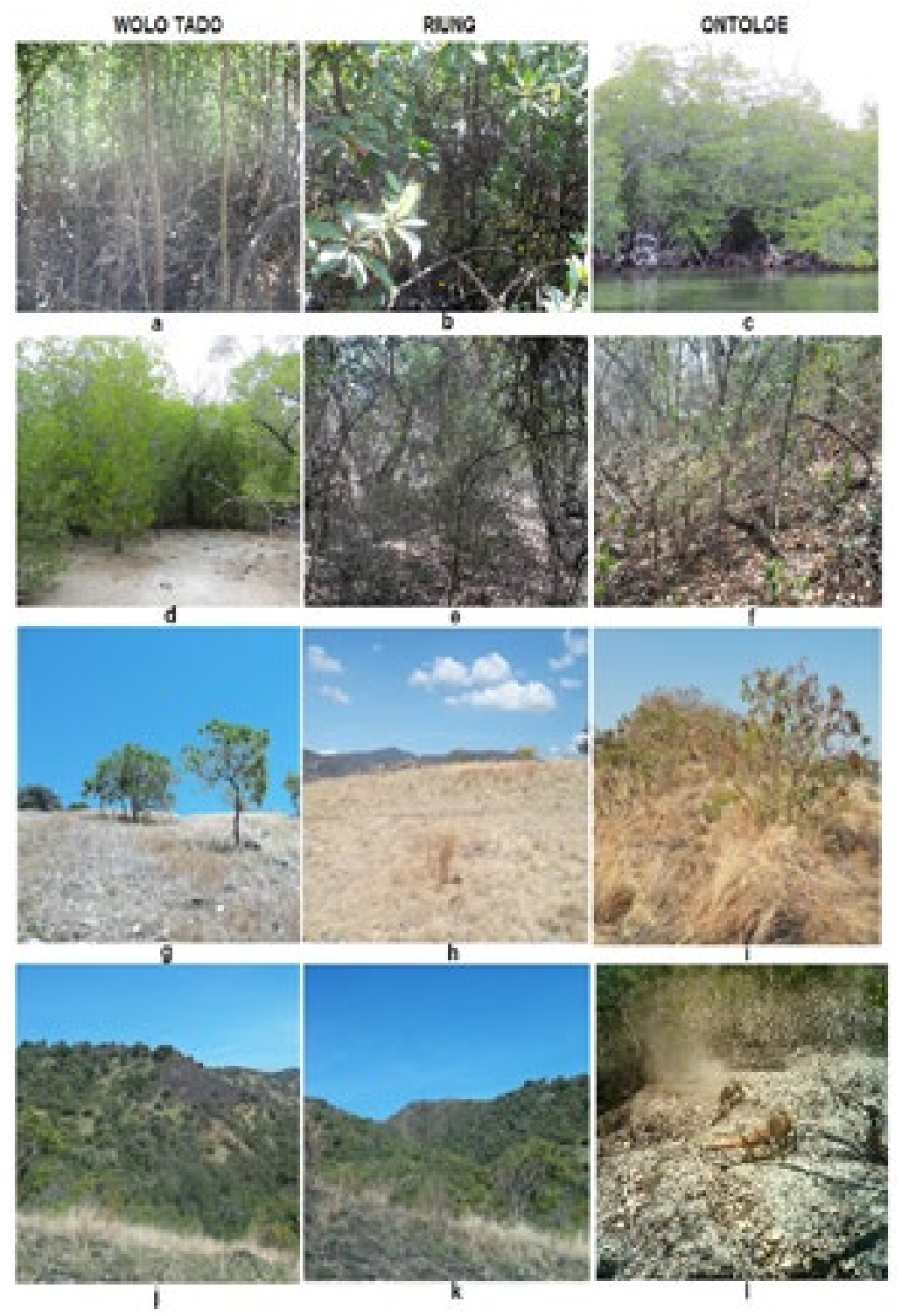

Gambar 3. Ekosistem Hutan Bakau: a) Wolo Tadho; b) Riung; c) Ontoloe Zona middle; d) Ontoloe Zona upper; Ekosistem Hutan Ekoton: e) Wolo Tadho; f) Ontoloe; Sabana Woodland: g) Wolo Tadho; h) Riung; i) Ontoloe; Hutan Legong: j) Wolo Tadho; k) Riung; l) Komodo menggali bekas lubang M. reinwardt. 
Dominansi C. tagal untuk pohon, sapling dan seedling karena kemampuannya beradaptasi terhadap salinitas yang lebih tinggi (130 0/00) sebab daun memiliki kelenjar garam. Kelenjar garam di daun mampu mengatur kadar garam dalam tubuh (Kitamura et al. 1997). Selain itu, C. tagal memiliki akar banir sehingga mampu tumbuh dengan baik di tekstur tanah berpasir (70,08\%). Pertumbuhan C. tagal merespon temperatur cahaya dan temperatur tinggi yang disebabkan oleh adanya gap vegetasi (Barbour et al. 1987).

Kerapatan pohon dan sapling di ekosistem hutan bakau CA Wolo Tado dan CA Riung mempengaruhi tidak masuknya cahaya sehingga seedling tidak dapat bertumbuh dengan baik. Seperti telah dibicarakan sebelumnya bahwa hal ini sebagai respon temperatur di gap vegetasi. Sebaliknya di Ontoloe terdapat seedling C. tagal sebanyak 192 individu per 0,16 ha di zona upper. Jenis seedling yang ada di zona middle Ontoloe yaitu S. alba 16 individu, R. mucronata 5, C. tagal 3 dan B. stylosa 1. Cahaya yang masuk ke dasar hutan bakau dimanfaatkan oleh seedling untuk bertumbuh baik serta merespon kandungan NO3 (80,87 ppm) dan NH4 (121,31 ppm).

Ekositem Hutan Ekoton - Ekosistem hutan ekoton ditemukan di pulau Flores yaitu Wolo Tado dan di pulau Ontoloe. Wolo Tado memiliki cacah jenis native lebih tinggi yaitu S. ovata 24 individu dan C. monoica 23 per 0,16 ha. Kehadiran jenis L. glauca merupakan hasil penanaman oleh warga. Pohon yang ditemukan di Wolo Tado yaitu L. glauca 36 individu dan sapling 19 per 0,16 ha. Growthform pohon, sapling, seedling dan semak pun lebih tinggi di Wolo Tado daripada di Ontoloe sebab tekstur tanah liat tinggi di Wolo Tado sehingga mampu menyimpan air lebih banyak daripada di Pulau Ontoloe yang berpasir (Gambar 7, 10).

Wolo Tado menyediakan habitat yang lebih banyak (MacArthur dan Wilson 1963) untuk pertumbuhan berbagai jenis pohon, sapling, seedling dan semak dalam 0,16 ha yaitu 11 jenis pohon, 10 jenis sapling, 2 jenis seedling dan 6 jenis semak. Kandungan NO3, $\mathrm{NH} 4, \mathrm{PO} 4$ dan

K tersedia di Wolo Tado lebih rendah daripada di Ontoloe (12,6 ppm, 15,75 ppm, 0,12\%, 2,35 me/100 g), tapi tekstur tanah lempung (35,73\%) lebih tinggi daripada di Pulau Ontoloe. Tanah lempung mampu menahan air lebih banyak. Suhu yang lebih rendah (udara: 290C dan tanah: 280C) juga mendukung pertumbuhan vegetasi (Gambar 7). Suhu rendah

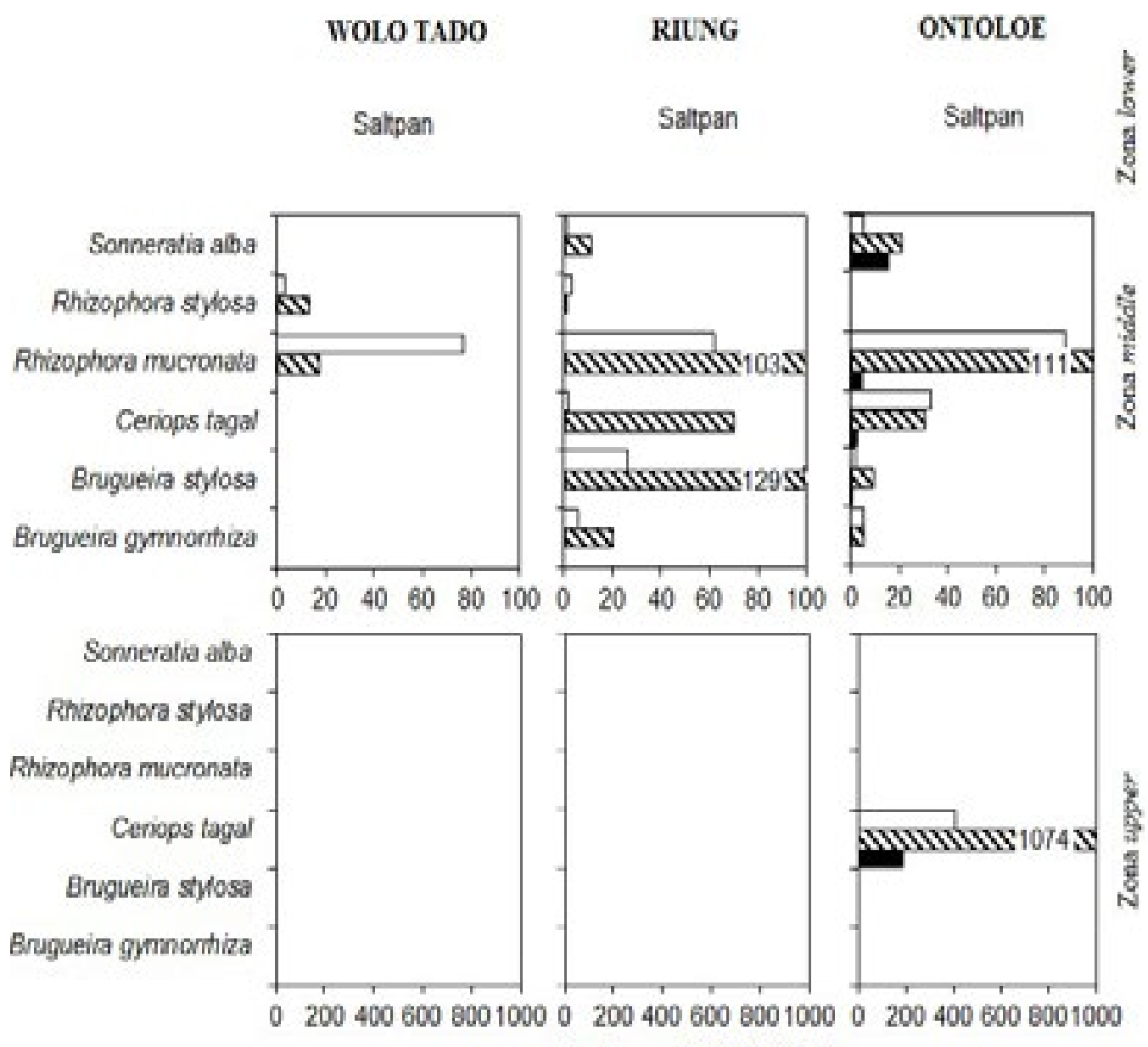

Gambar 4. Densitas tiap jenis penyusun gowth form vegetasi hutan bakau di Pulau Besar yaitu di Wolo Tado dan Riung dan Pulau Kecil yaitu Ontoloe. Zona lower tidak terdapat hutan bakau. Zona middle didominasi sapling pada Ontoloe dan Riung. Zona upper ditemukan hanya ada di Ontoloe, hanya Ceriops tagal. : Pohon, : Sapling, : Seedling. 


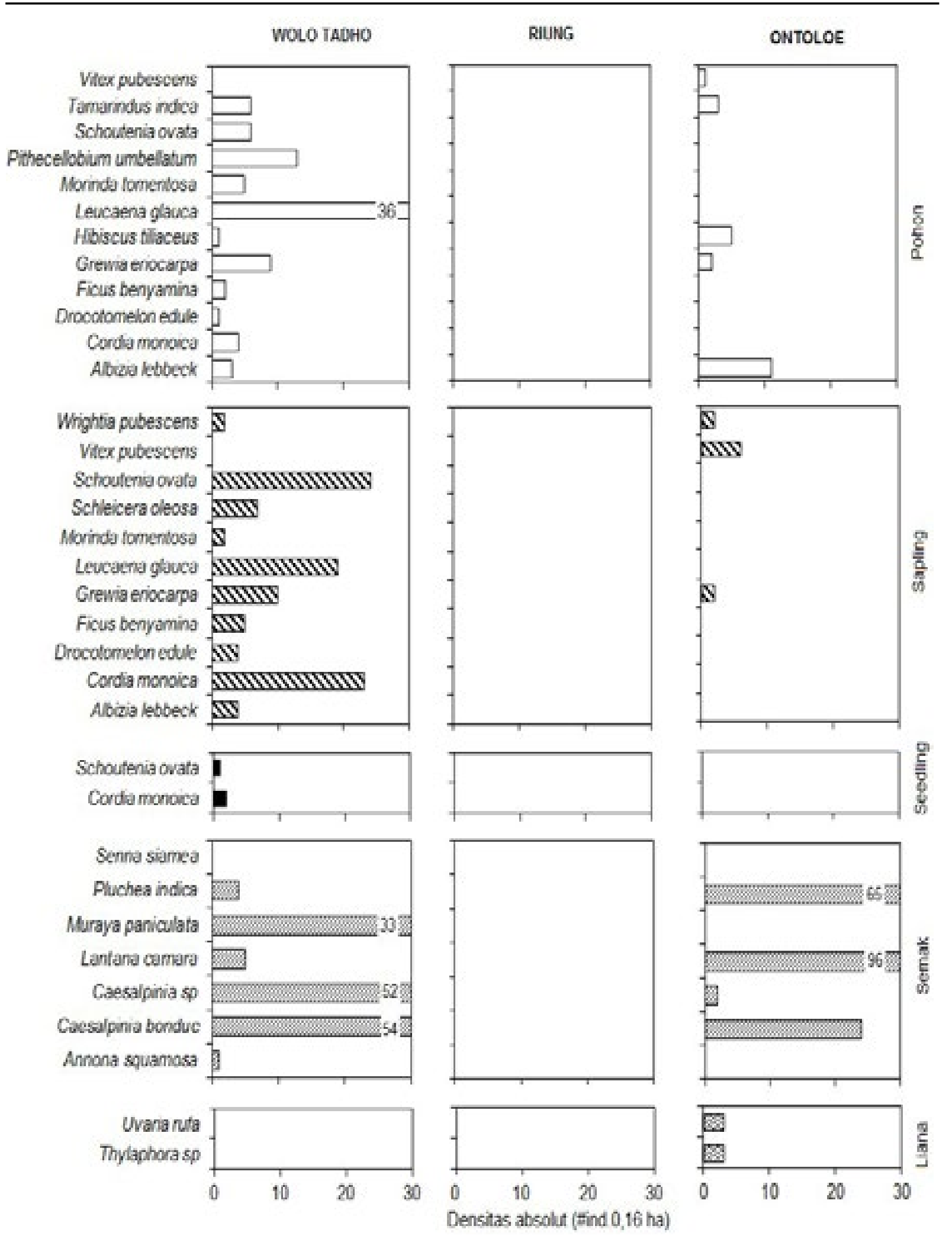

Gambar 5. Densitas tiap jenis penyusun growth form vegetasi hutan ekoton di Wolo Tado, Riung dan Ontoloe. Cacah jenis dan jumlah jenis terbanyak ada di Wolo Tado: growthform pohon yaitu Leucaena glauca dan sapling yaitu Cordia monoica dan Schoutenia ovata. Riung tidak memiliki hutan ekoton, : Pohon, : Sapling, : Seedling, : Semak, : Liana. 


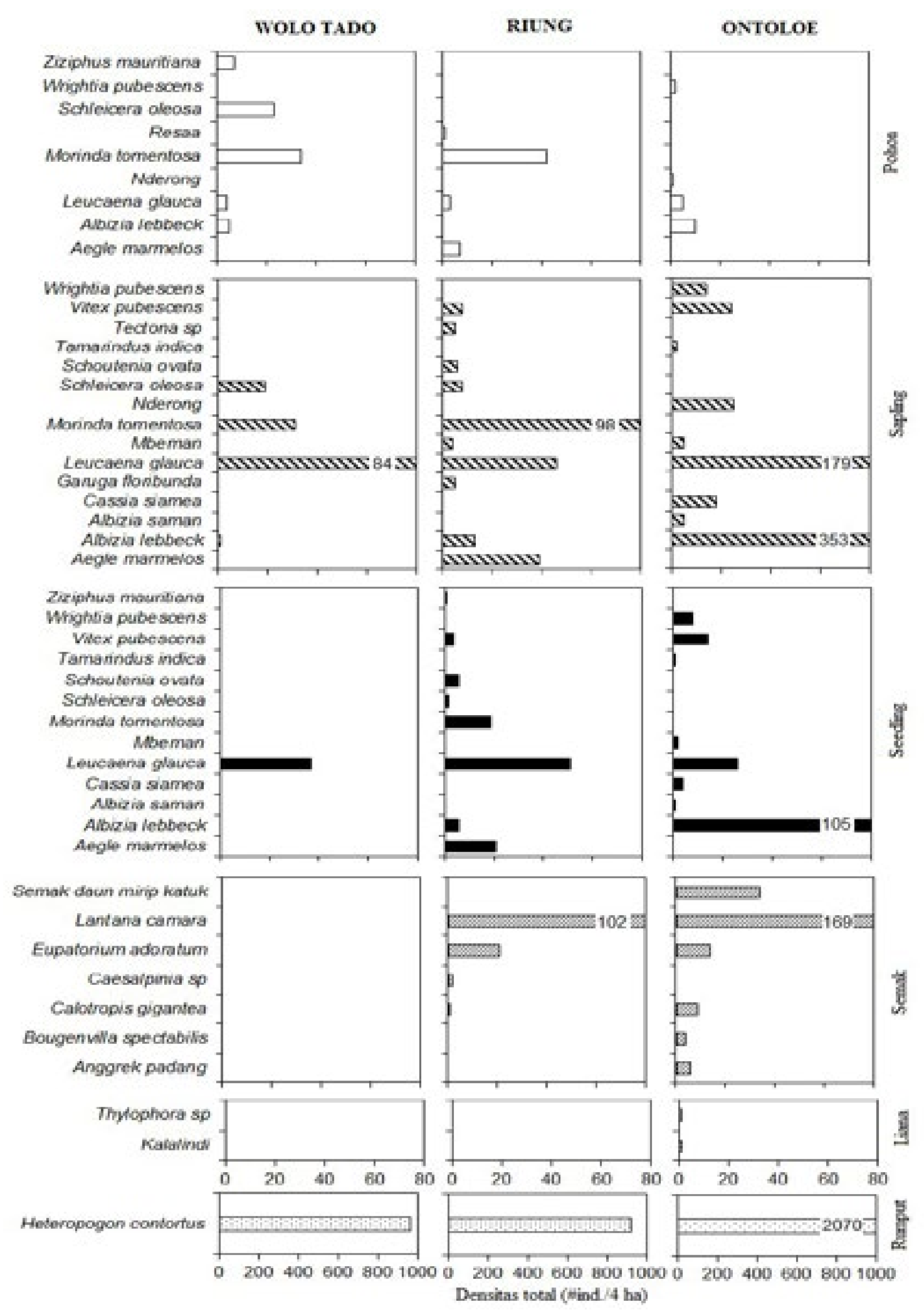

Gambar 6. Densitas tiap jenis penyusun growth form vegetasi hutan sabana di Wolo Tadho, Riung dan Ontoloe. : Pohon, : Sapling, : Seedling, : Semak, : Liana. 


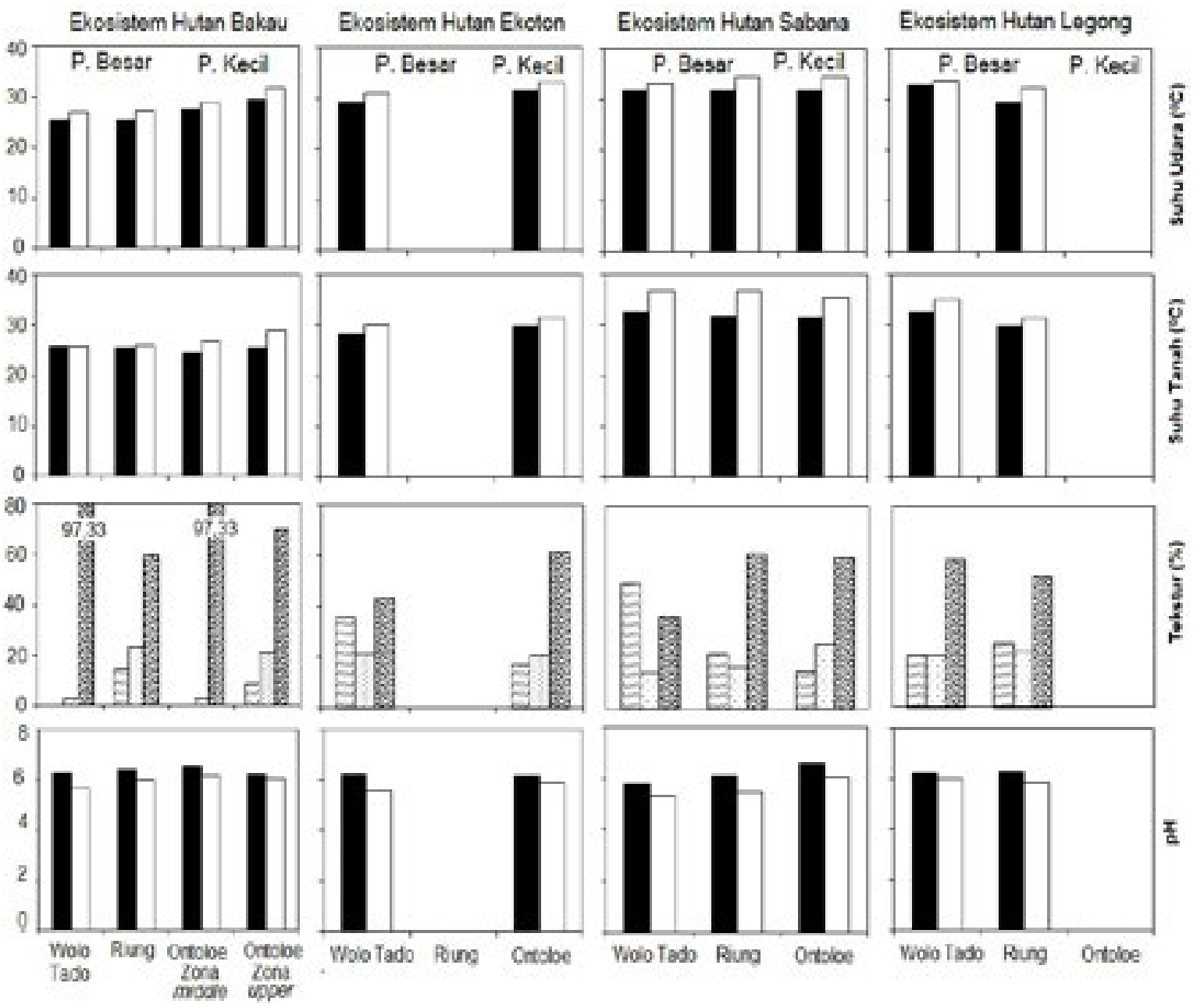

Gambar 7. Parameter fisikokimia lokasi kajian. Pulau Besar: Wolo Tado dan Riung, Pulau Kecil: Ontoloe : kanopi, : gap kanopi, : lempung (\%), : debu (\%), : pasir (\%), ; NO3 tanah (ppm), PO4 total tanah (ppm), : NH4 tanah (ppm), : K tersedia tanah (me/100mg).

mengurangi penguapan sehingga baik untuk mendukung pertumbuhan vegetasi. Semak di Wolo Tado tetap hidup dengan cacah individu tinggi yaitu Caesalpinia bonduc 54 individu per 0,16 ha. Semak ini menggugurkan daun untuk beradaptasi terhadap ketersediaan hara yang tipis dan temperatur yang tinggi. Liana hanya ditemukan di Ontoloe (Gambar 5). Distribusi U. rufa dan Thylaphora sp, didukung oleh tidak adanya usikan dari manusia misalnya oleh penebasan dan pembakaran. Ukuran batang $U$ rufa dan Thylaphora sp., berdiameter antara $4-13 \mathrm{~cm}$ sebab mampu mengoptimalkan $\mathrm{K}$ tersedia, NO3, NH4 dan PO4. Pertumbuhan liana ke atas untuk berkompetisi dengan pohon T. indica untuk memperoleh cahaya. Ekoton Wolo Tado dilalui oleh jalan raya dengan lebar kurang lebih 2 meter. Hal ini mempengaruhi migrasi dan pemencaran vegetasi termasuk komodo, rusa, anak sapi, kambing dan babi liar. Pada pinggiran jalan telah dilakukan penyebaran benih L. glauca. Penyebarannya bertambah dan mendominasi ekoton.

Ekosistem hutan sabana - Tumbuhan M. tomentensa merupakan jenis native yang banyak ditemukan di pulau Flores yaitu Wolo Tado 34 individu dan Riung 42 individu. Kemampuan adaptasi terhadap temperatur tinggi, kekurangan air dan lapisan tanah yang tipis menjadi penting. Selain itu, M. tomentosa mampu beradaptasi terhadap api (fire tolerant) yaitu batang yang tidak mudah terbakar sehingga jika ada pembakaran skala kecil di hutan sabana akan tetap hidup (resprout). Sapling M. tomentosa ditemukan 84 individu di Riung (Gambar 6).

Jenis non native yaitu L. glauca dan A. lebbeck banyak ditemukan di Ontoloe terutama sapling yaitu 179 dan 353 individu per 4 ha. Distribusi kedua jenis ini di Ontoloe sejak adanya usaha revegetasi atas inisiatif seorang biarawan di tahun 2001. L. glauca dan A. lebbeck mampu beradaptasi terhadap kekurangan air, temperatur tinggi $(32,90 \mathrm{C})$ dan tanah tipis di bentanglahan karst (Prietekel et al 2006; Viani et al 2014). Selain itu kemudahan untuk menumbuhkan dan sumber kayu menjadi alasan pilihan jenis ini ditanam (Mahsurin 2014: pers comm). Akan tetapi kehadiran non native akan mengkoloni dan mendominasi vegetasi native sehingga akan terjadi pengubahan ekosistem 


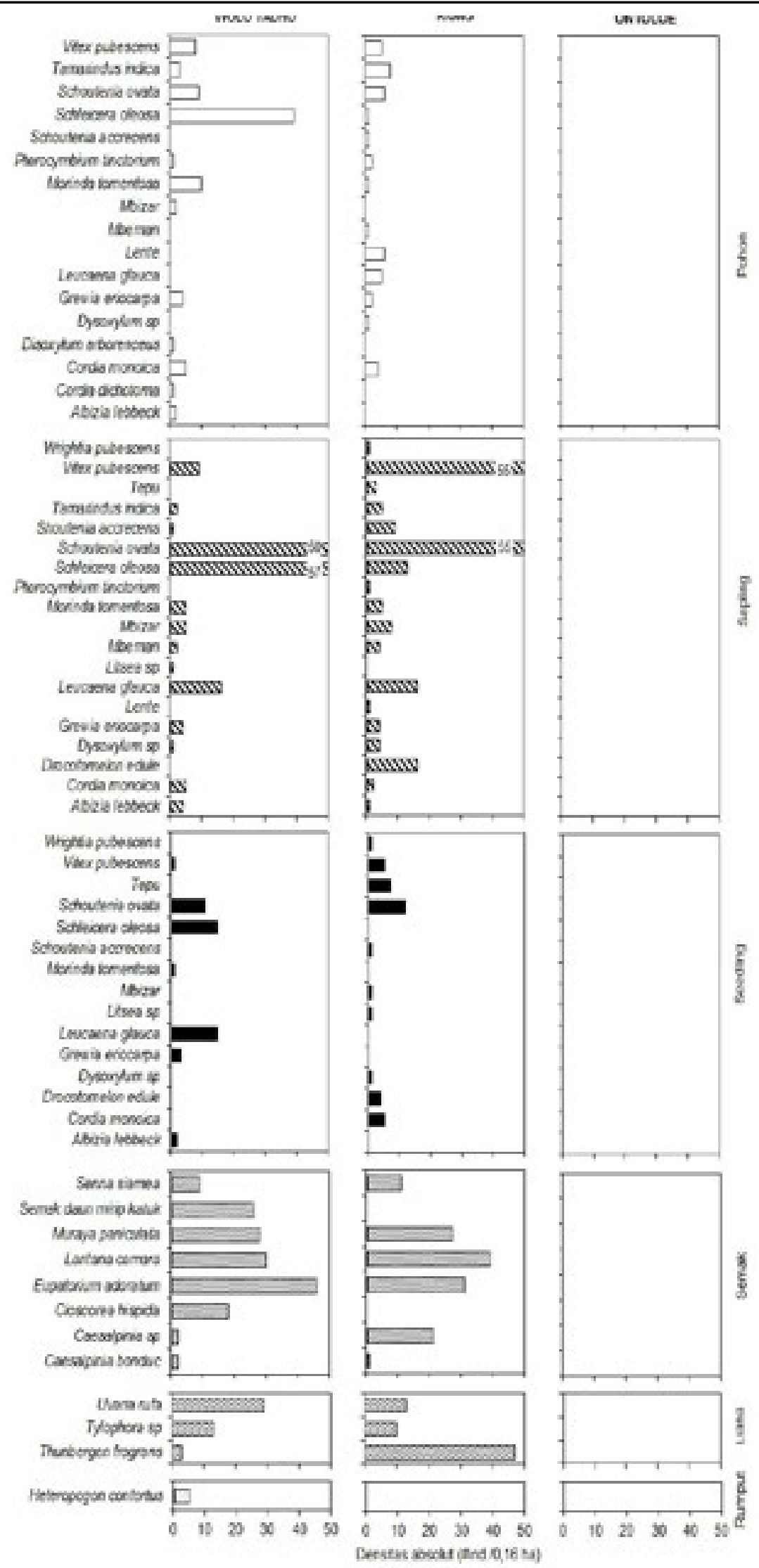

Gambar 8. Densitas tiap jenis penyusun growth form vegetasi hutan legong Wolo Tado, Riung dan Ontoloe, : Pohon, : Sapling, : Seedling, : Semak, : Rumput, : Liana. 


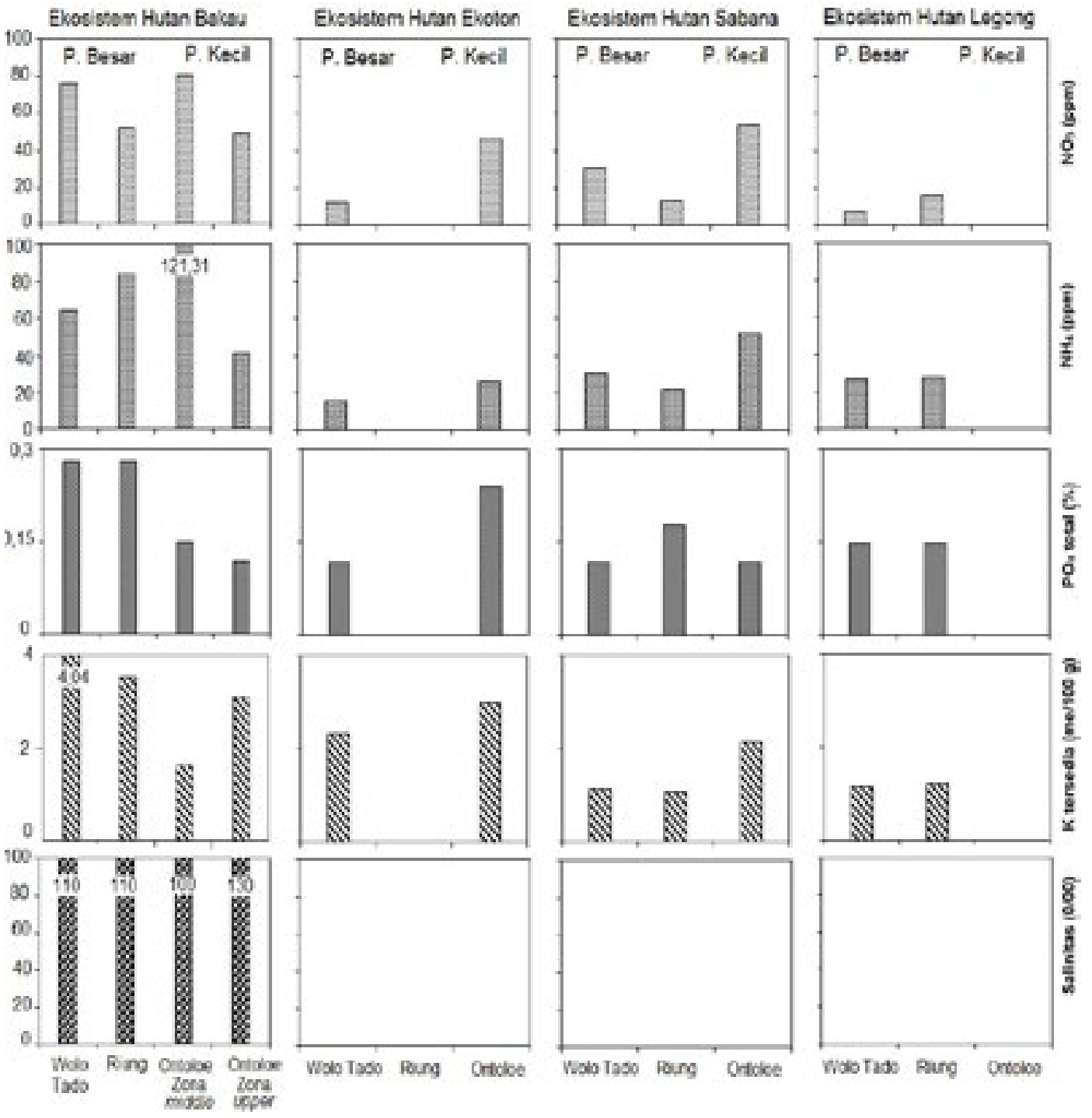

Gambar 9. Parameter fisikokimia lokasi kajian. Pulau Besar: Wolo Tado dan Riung, Pulau Kecil: Ontoloe : kanopi, : gap kanopi, : lempung (\%), : debu (\%), : pasir (\%), ; NO3 tanah (ppm), PO4 total tanah (ppm), : NH4 tanah (ppm), : K tersedia tanah (me/100mg), : Salinitas air hutan bakau (0/00).

alami (Walter 1971; Walker dan Smith 1997; Zhu et al 2001; Yuan et al 2011). Hal ini menyebabkan dominansi semak di Ontoloe.

Semak E. odoratum ditemukan di Ontoloe 169 individu per 4 ha. Distribusi semak di Ontoloe membentuk kelompok (gerombol). Kemampuan penyebaran benih yang cepat (r-seleksi dan K-seleksi) meningkatkan densitas E. odoratum di Ontoloe (Barbour et al.1987). Di Riung, pembakaran skala kecil jarang dilakukan sehingga ditemukan E. odoratum (102 individu per $4 \mathrm{ha}$ ) yang tersebar (scatter) dan kelompok kecil dibandingkan di Ontoloe.

Jenis yang ada yaitu Heteropogon contortus, L. camara, L. glauca dan M. tomentosa. Tekstur tanah berpasir (Gambar 7) tinggi di Riung dan Ontoloe $(61,31 \%$ dan 59,81\%). Tekstur lempung tinggi di Wolo Tado (49,71\%). Hal ini mempengaruhi kemampuan menahan air saat terjadi hujan. Mahsurin, Perry dan Kaliks (2015: pers comm) menyatakan di Riung dan Onoloe air lebih cepat kering setelah terjadi hujan daripada di Wolo Tado. Temperatur udara dan tanah yang tinggi mempengaruhi distribusi dan kemelimpahan vegetasi.

Ekosistem hutan legong - Hutan legong merupakan kali intermitten. Tumbuhan native ditemukan di pulau Flores yaitu Wolo Tado dan Riung. Distribusi di Wolo Tadho yaitu S. oleosa (57 individu per 0,16 ha) dan S. ovata (50 individu per 0,16 ha). Di Riung ditemukan S. ovata ( 55 individu per 0,16 ha). Kedua jenis merupakan jenis desiduous yang ada di hutan legong. Variasi growth form dengan ciri desiduous didukung oleh tekstur tanah lempung dan debu cukup tinggi (Gambar 7) di Wolo Tado $(20,43 \%$ dan $20,67 \%)$ dan Riung $(25,81 \%$ dan $22,48 \%)$. Tekstur berpasir tetap paling tinggi $(58,91 \%$ dan $51,71 \%)$.

Adanya lempung dan debu maka kemampuan 


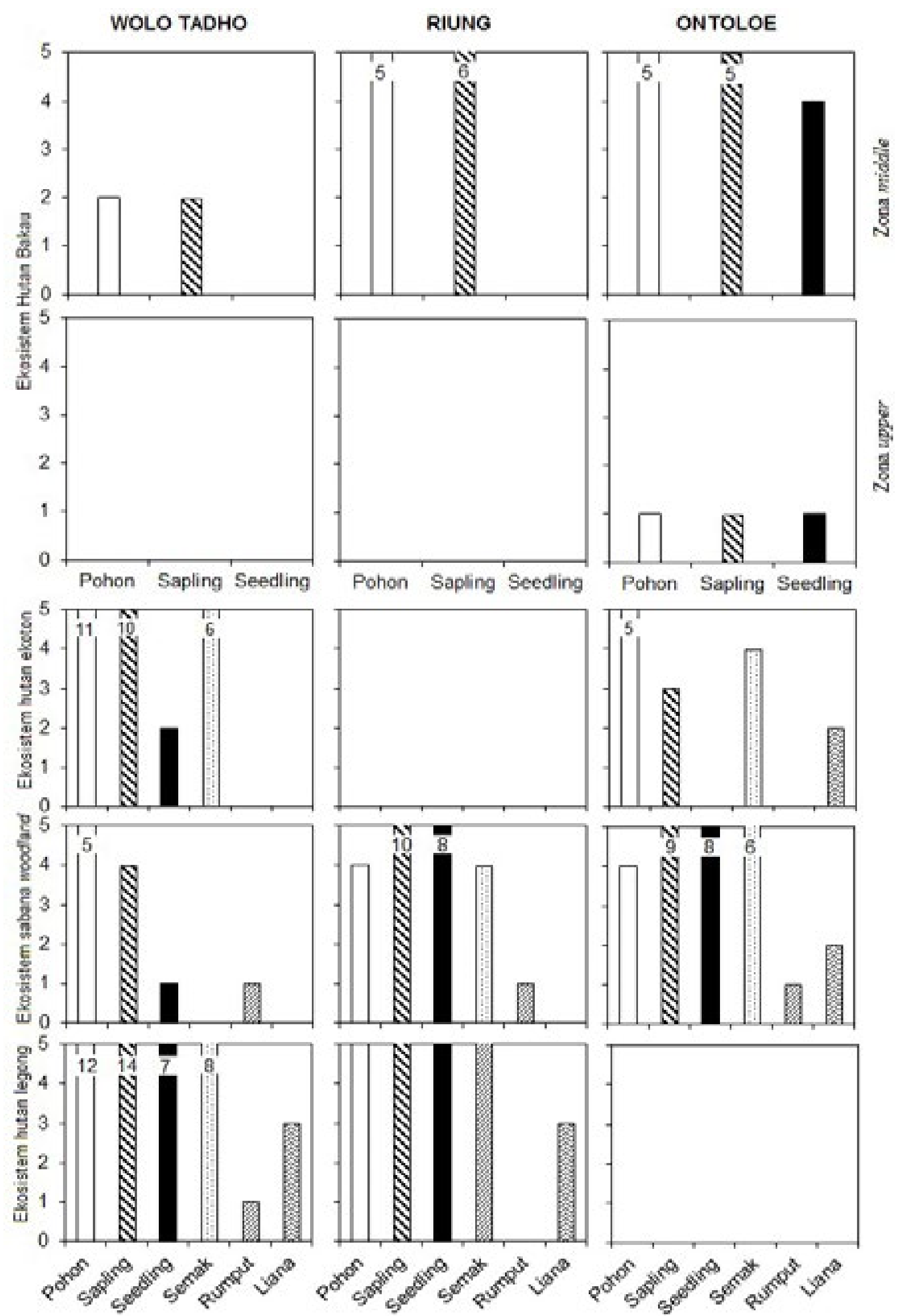

Gambar 10. Cacah jenis vegetasi penyusun ekosistem hutan bakau, hutan ekoton, sabana woodland dan hutan legong di Wolo Tadho, Riung dan Ontoloe, : Pohon, : Sapling, : Seedling, : Semak, : Rumput, : Liana. 
menahan air sedikit lebih baik. Seperti yang telah dijelaskan sebelumnya bahwa air permukaan di Wolo Tado lebih lama bertahan setelah hujan daripada di Riung. Wolo Tado memiliki growth form lebih tinggi daripada di Riung yaitu pohon, sapling, seedling, semak, liana dan rumput (Gambar 10). Distribusi rumput di hutan legong Wolo Tado hanya di tepi. Aliran air hujan yang membawa benih memungkinkan migrasi rumput di hutan legong. Densitasnya sangat terbatas (5 gerombol kecil).

Kompetisi di bawah naungan pohon besar (gap kanopi) sehingga distribusi rumput hanya ditemukan di tepi hutan legong (Krebs 2009). Distribusi L. glauca di Wolo Tado pun dipengaruhi pemencaran benih di kemiringan hutan legong. Buah yang matang memencarkan biji dan terbawa aliran air. Distribusi semak mengoptimalkan gap vegetasi untuk hidup (33,80C), (NH4 27,29 ppm dan 27,58; 0,15\% dan 0,15; $\mathrm{K}$ tersedia $1,17 \mathrm{me} / 100 \mathrm{mg}$ dan 1,23$)$. Nutrien dari serasah yang hancur dan bersiklus di dalam ekosistem hutan legong sehingga menjaga kandungan nutrien di dalam ekosistem ini.

Ordinasi - Ordinasi mengelompokan ekosistem hutan bakau terdiri dari dua kelompok zona (Gambar 11) yaitu zona middle di pulau besar $(2,3,4,5,6,7,8$ dan 11) dan zona middle dan upper di Pulau Kecil (1, 9, 10, 12, 13, 14, 15 dan 16). Kelompok pertama didominasi oleh R. mucronata (139 pohon dan sapling per 0,16 ha) dan R. stylosa (6 pohon dan sapling per $0,16 \mathrm{ha}$ ). Sebaliknya zona-zona di pulau kecil didominasi oleh C. tagal (441 pohon, 1114 sapling dan 195 seedling) per 0,16 ha. Sepertiyang telah dijelaskan sebelumnya, kehadiran jenis dominan R. mucronata, R. stylosa dan C. tagal sebagai respon terhadap salinitas zona middle yang mirip antara Wolo Tado dan Riung (Gambar 11). Selain kemiripan tanah berpasir ada kemiripan nilai temperatur udara, temperatur tanah, $\mathrm{pH}, \mathrm{PO} 4$ dan $\mathrm{K}$ tersedia. Hal ini berbeda dengan kelompok di hutan bakau pulau Ontoloe. Sekali lagi dominansi C. tagal sebagai respon salinitas tinggi (130 0/00) dan respon tekstur berpasir dan temperatur tanah dan udara.

Hasil ordinansi zona-zona yang mengelompok antara lain di Wolo Tado yaitu 1, 2, 3 , 4 dan di Ontoloe yaitu zona 7 (Gambar 11). Jenis yang ada di kelompok ini adalah Caesalpinia bonduc, Cordia monoica, Grewia eriocarpa, Leucaena glauca, Morinda tomentosa, Muraya paniculata, Pithecellobium umbelatum, Schoutenia ovata, Sebaliknya zona 5 dan 6 di Ontoloe mengelompok di kelompok tersendiri. Jenis yang ada yaitu Caesalpinia bonduc, Lantana camara. Kehadiran jenis-jenis tersebut terutama semak dominan yaitu C. bonduc dan L. camara merespon kekurangan air dan temperatur (Achmad 2011; Liu et al 2012). Tekstur pasir Wolo Tado dan Ontoloe (43,07\% dan 61,52\%), NO3 (12,6 ppm dan 47,37), NH4(15,75 ppm dan 26,65).

Ordinasi ekosistem hutan sabana menunjukkan hasil ditemukan kemiripan semua zona baik di Wolo Tado, Riung dan Ontoloe (zona 1-12). Zona yang membentuk kelompok (Gambar 11) yaitu zona 3 dan 4 di Wolo Tado, 7 di Riung dan 12 di Ontoloe. Kehadiran rumput $H$. contortus menjadikan zona tersebut mirip sebab H. contortus telah beradaptasi terhadap tekstur bentang alam karst yang berpasir dan jumlah air tanah yang sedikit. Adanya pembakaran sabana berskala kecil pun memicu pertumbuhan rumput muda dan semak muda.

Ordinasi zona 2 dan 5 mengelompok (Gambar 11). Sebaliknya zona kelompok lainnya yaitu 1, 3,4, 6, 7 dan 8). Jenis di zona 2 dan 5 yaitu C. monoica, Dysoxylum sp, E. odoratum, G. eriocarpa, L. camara, S. oleosa, S. ovata,T. indica, V. pubescens. Seperti yang telah dijelaskan sebelumnya, pengelompokkan ini merespon ketersediaan nutrient yang berasal dari serasah. Kemiripan ekosistem hutan legong di Wolo Tado dan Riung $(54,9 \%)$ didukung oleh ketersediaan nutrient untuk vegetasi yang berasal dari serasah (Gambar 9).

Bukti tipe ekosistem sebagai habitat komodo - Jejak kaki komodo dan rusa ditemukan di Pulau Besar yaitu di CA Riung (Kalis 2014: pers comm). Komodo bergerak untuk mencari mangsa yaitu rusa, anak sapi, kerbau, kambing di ekosistem hutan bakau. Rusa bergerak untuk mencari air minum. Kami tidak menemukan jejak komodo dan jejak mangsa di CA Wolo Tado. Di Pulau Kecil, kami menemukan jejak kaki, jejak tangan, jejak kaki dan kotoran komodo, kera dan kalelawar. Komodo ditemukan memanjat pohon R. mucronata (Sipri J 2014: pers comm) dan memangsa kalelawar (Ariefiandy 2014: pers comm). Populasi rusa semakin berkurang, tapi belum pernah dilakukan perkiraan jumlah populasi untuk saat ini (Sipri J 2014: pers comm).

Seekor V. komodoensis ditemukan bergerak dari hutan bakau ke hutan ekoton di Pulau Besar yaitu di Wolo Tado (Tjut 2014: pers comm). Ekosistem hutan ekoton tidak ada di Riung. Di Pulau Kecil, hasil survei tim BKSDA Riung dan Komodo Survival Program menemukan sarang $M$. reinwardt yang diambilalih oleh V. komodoensis. Sarang ini merupakan sarang aktif dengan indikasi ditemukannya aktivitas galian oleh V. komodoensis yang ditangkap oleh kamera trap (Gambar 2L, courtesy kamera trap KSP).

Pada ekosistem hutan sabana, di Wolo Tado dan Riung ditemukan B. taurus dan C. aegarus yang bergerak dalam beberapa kelompok kecil yaitu 5-10 ekor. Ternak tersebut merupakan ternak warga yang dilepas-liar untuk mencari rumput $\mathrm{H}$. contortus di hutan sabana. Selain itu, ditemukan jejak kaki dan kotoran V. komodoensis, C. timorensis, B. taurus, dan C. aegagrus. Lalu di temukan kandang dan bekas patok B. taurus dan C. aegagrus. Ciofi dan de Boer (2004) menemukan juvenile komodo yang bergerak di antara celah batu di hutan sabana untuk mencari perlindungan. Di Pulau Kecil, ditemukan jejak kaki dan kotoran V. komodoensis. Selain H.contortus, di hutan sabana Pulau Ontoloe ditemukan L. glauca dan A. lebbeck. Kedua komunitas dimanfaatkan sebagai 

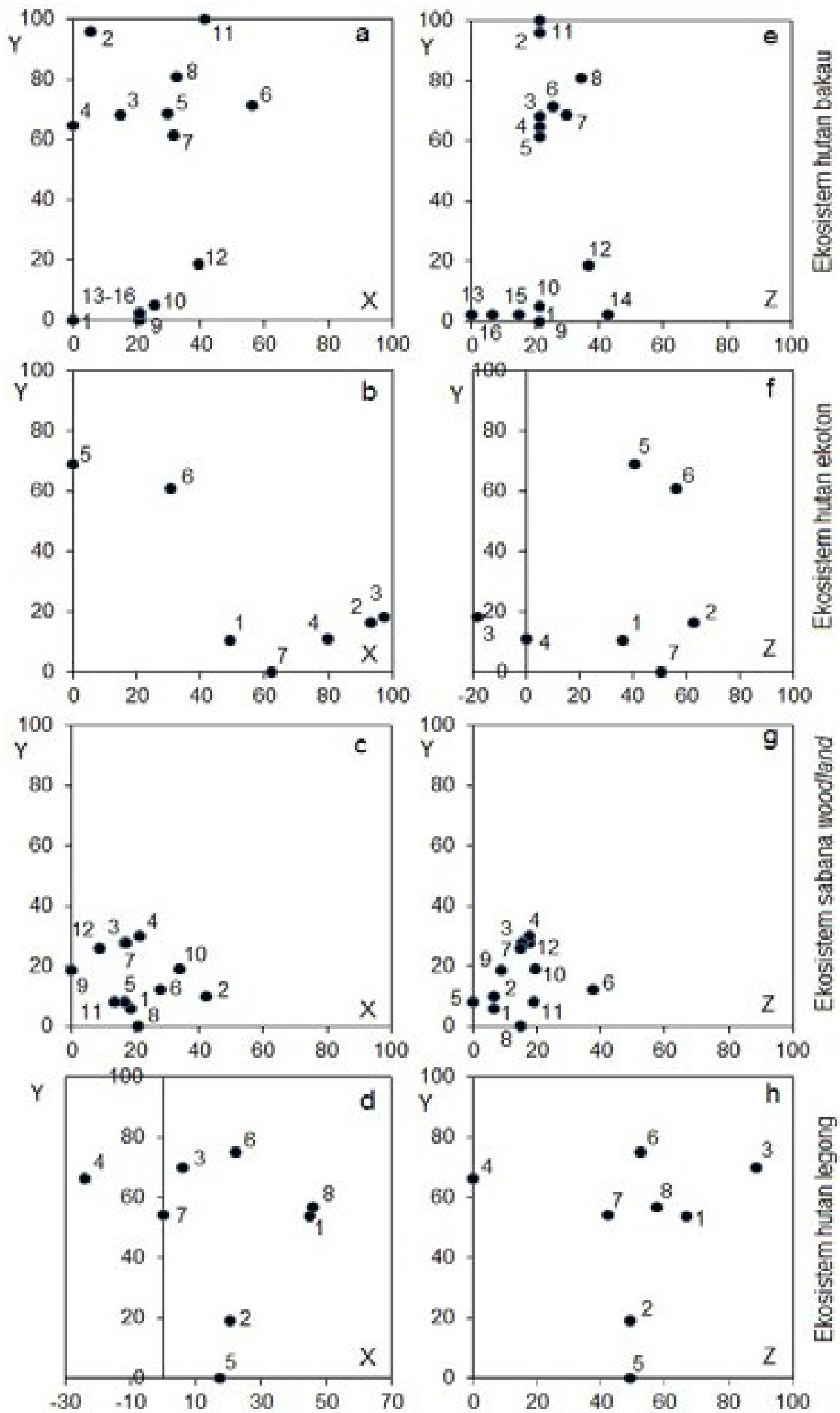

Gambar 11. Ordinasi ekosistem di Pulau Besar dan Pulau Kecil: a, b, c dan d). Letak setiap zona terhadap aksis X-Y; e, f, g dan h). Letak setiap zona terhadap aksis Z-Y. Zona di ekosistem hutan bakau mirip ditandai dengan zona yang mengelompok atau berjarak lebih dekat daripada zona di ekosistem hutan bakau, ekosistem hutan legong dan ekosistem hutan ekoton. 
habitat oleh M. fascularis dan Gallus gallus, yang ditandai dengan bekas gigitan M. fascularis dan kotoran G. gallus di batang L. glauca. Akan tetapi, data tidak dicuplik pada lokasi tersebut. Pada ekosistem hutan legong Pulau Besar yaitu Wolo Tado, ditemukan jejak kaki dan kotoran C. timorensis. Pada musim hujan, C. timorensis meminum air yang tergenang di ekosistem hutan legong. Sedangkan pada musim panas, rusa sering berteduh di sini (Mahsurin 2014: pers comm). Jejak kaki V. komodoensis dan rusa tidak ditemukan di ekosistem hutan legong Riung. Usaha melindungi komodo dari ancaman (IUCN 2004) dilakukan dengan melindungi keberlanjutan vegetasi penyusun habitat komodo.

\section{KESIMPULAN}

Vegetasi penyusun habitat di Pulau Besar atau Flores dan Pulau Kecil atau Ontoloe sangat penting bagi distribusi dan kemelimpahan populasi V. komodoensis. Zona hutan bakau di Pulau Besar yaitu zona middle dan zona di Pulau Ontoloe yaitu zona middle dan zona upper. Ketersediaan vegetasi di ekosistem hutan bakau di Pulau Besar dan Pulau Kecil didominasi oleh R. mucronata. Pohon R. mucronata penting di Pulau Ontoloe sebab di ujung batang menjadi habitat Cynoptera sp., sebagai pakan V. komodoensis. Ketersediaan sabana di hutan sabana di Pulau Besar menjadi sumber makanan rusa, sebagai pakan bagi V. komodoensis. Ketersediaan sabana terjaga oleh pembakaran sabana berskala kecil. Larangan pembakaran sabana oleh pemerintah mengusik ketersediaan sabana di Pulau Besar. Sebaliknya di Pulau Kecil, tidak ada pembakaran sabana berskala kecil di hutan sabana menimbulkan ancaman invasi oleh semak L. camara.

\section{UCAPAN TERIMAKASIH}

Terima kasih kepada Prof. Dr. Tjut Sugandawaty Djohan, M.Sc., dan Prof. Dr. Su Ritohardoyo, MA., atas bimbingan, pencerahan dan kesabaran selama proses persiapan, penelitian dan penulisan hasil penelitian. Penelitian ini didukung oleh bantuan dana dari Lembaga Pengelola Dana Pendidikan (LPDP). Terima kasih kepada Kakak Ariefiandy, M.Sc., Krisni Suhestiningsih, M.Sc., dan Aji A. Akbar, M.Sc., atas bantuan material dan kritikan untuk penulisan laporan. Terima kasih kepada Pak Yono dan Pak Tukijan dari Lab. Konservasi Biologi UGM atas bantuan penggunaan alat, rekan-rekan yang sudah membantu pembuatan tabel analisis dan dukungan semangat: Dawam, Jhon, Rifky, Arum, Nika, Ira. Saya juga mengucapkan terima kasih atas dukungan yang tiada henti oleh kedua orang tua: Bapak David B. Blegur dan Mama Bernadetha E. Fernandez, kepada semua adik tercinta: Mariana, Natalia, Ebenhaezer, Samu dan sahabat terkasih Sarci serta semua keponakan: Dev, Amy, Kyara, Sania, Ira, Rimba.

\section{DAFTAR PUSTAKA}

Achmad, A. (2011). Rahasia Ekosistem Hutan Bukit
Kapur. Surabaya: Brillian International

Auffenberg, W. (1981). The Behavioral Ecology of the Komodo Monitor. Gainesville: University Presses of Florida.

Barbour, M.G, J.H. Burk dan W.D. Pitts. (1986). Terresterial Plant Ecology, 2nd Ed. California: The Benjamin/Cummings Publishing Company, Inc.

Brewer, J.E dan J. H. Zar. (1984). Field and laboratory methods for general ecology 2nd. Dubuque: Wm. C. Brown Publ.

Ciofi, C., dan M. E. de Boer. (2004). Distribution and Conservation of the Komodo Monitor (Varanus komodoensis). Herpetological 14: 99 - 107.

Djohan, T. S., (2014). Petunjuk Praktikum Ekologi Lanjut Biologi. Laboratorium Ekologi dan Konservasi, Fakultas Biologi, Universitas Gadjah Mada, Fakultas. Yogyakarta.

de Garine-Wichatitsky, M., Y. Soubeyran, D. Maillard dan P. Duncan. (2005). The diets of introduced rusa deer (Cervus timorensis russa) in a native sclerophyll forest and a native rainforest on New Caledonia. New Zealand Journal of Zoology 32: $117-126$.

Fuping, Z., P. Wanxia, S. Tongqing, W. Kelin, W. Haiyong, S. Xijuan dan Z. Zhaoxia. (2007). Changes in vegetation after 22 years' natural restoration in the karst disturbed area in northwestern Guangxi, China. Acta Ecologica Sinica 27: 5110-5119.

Ginantra, K., S. Putra, W. Suarna dan W. Kasa. (2014). Botanical Composition of forage by Timor Deer (Cervus timorensis Blainville) in A Monsoon Forest and Savanna of West Bali National Park. International Journal of Pure \& Applied Bioscience 2(5): 205-213.

Harlow, H.J., D. Purwandana, T.S. Jessop, dan J. A. Phillips. (2010). Body temperature and thermoregulation of Komodo dragons in the field. Thermal Biology 35: 338-347.

Hidayatullah, M. (2013). Pemanfaatan Mangrove oleh Masyarakat di Nusa Tenggara Timur. Warta Cendana Ed. VI No 2:9-15.

IUCN. (2004). A Global Species Assessment. Cambridge: Thanet Press Limited.

IUCN. (2008). World Heritage Caves and Karst: A Thematic Study. Switzerland: IUCN Programme on Protected Areas.

Jessop, T.S., J. Sumner, H. Rudiharto, D. Purwandana, M.J. Imansyah dan J.A. Phillips. (2004). Distribution, use and selection of nest type by Komodo Dragons. Biological Conservation 117: $463-470$.

Kitamura, S., C. Anwar, A. Chaniago dan S. Baba. (1997). Handbook of Mangrove in Indonesia: Bali \& Lombok. Denpasar: Penerbit Jaya Abadi.

Krebs, C.J. (2009). Ecology, 6th Ed. St. Fransisco: Pearson Education, Inc.

Liu, C.C., Y.G. Liu, D.Y. Fan and K. Guo. (2012). Plant drought tolerance assessment for re-vegetation in 
heterogeneous karst landscape of southwestern China. Flora 207: 30-38.

Lu, X., H. Toda, F. Ding, S. Fang, W. Yang dan H. Xu. (2014). Effect of vegetation types on chemical and biological properties of soils of karst ecosystems. European Journal of Soil Biology 61: 49-57.

MacArthur, R.H., dan E.O. Wilson. (1963). An Equilibrium Theory of Insular Zoogeography. Evolution 17 (4): 373-387.

Mitsch, W.J dan J.G. Gosselink. (2000). Wetland 3rd edition. Kanada: John Wiley \& Sons, Inc.

Muller - Dumbois, D., dan Ellenberg. (1974). Aims and methods of vegetation ecology. New York: John Wiley and Sons, Inc.

Ouwens, P.A. (1912). On a large Varanus species from the island of Komodo. Buletin Jardin Botanic Buitenzorgi 6: 1-3.

Primack, R.B., J. Supriatna, J. Indrawan, dan P. Kramadibrata. (1998). Biologi Konservasi. Jakarta: Penerbit Yayasan Obor Indonesia.

Pritekel, C., A. Whittemore-Olson, N. Snow, dan J.C. Moore. (2006). Impacts from Invasive Plant Species and Their Control on the Plant Community and Belowground Ecosystem at Rocky Mountain National Park, USA. Applied Soil Ecology 32:132141.

UNEP-CITES. (2013). Appendices I, II and III. Switzerland: International Environment House.

Iani, R.A.G., R.R. Rodrigues, T.E. Dowson, H. Lambers, dan R.S. Oliveira. (2014). Soil pH Accounts
Differences in Species Distribution and Leaf Nutrient Concentration of Brazilian Woodland Savannah and Seasonally Dry Forest Species, Perspective in Plant Ecology. Evolution and Systematics 16:64-74.

Walker, L.R., dan S.D. Smith. (1997). Impacts of Invasive Plants on Community and Ecosystem Properties. In Luken, J.O., dan J.W. Thieret, Assessment and Management Plant Invasions. New York: Penerbit Springer, p: 69-86.

Walter, H. (1971). Ecological of Tropical and Subtropical Vegetation. New York: Van Nostrand Reinhold Company, 207-265 pp.

Xiangkuna, Q., W. Kelina and Z. Chunhua. (2013). Effectiveness of ecological restoration projects in a karst region of southwest China assessed using vegetation succession mapping. Ecological Engineering 54: 245-253.

Yuan, W., Y.L. Fei, Z.J. Chi, Y.Y. Chun and D.L. Deanglis. (2011). Relationship between vegetation restoration and soil microbial characteristics in degraded karst regions: a case study. Pedosphere 21: 132-138.

Zhu, H., X. He, K. Wang, Y. Su dan J. Wu. (2011). Interactions of vegetation succession, soil biochemical properties and microbial communities in a karst ecosystem. European Journal of Soil Biology 51: 1-7. 